\title{
The Meaning of K-Pop and Self-Concept Transformation of K-Pop Fans in Bandung
}

\author{
${ }^{1}$ ALEX SOBUR, 2 FERRY DARMAWAN, ${ }^{3}$ RATRI RIZKI KUSUMALESTARI, \\ ${ }^{4}$ ENDRI LISTIANI, ${ }^{5}$ DADI AHMADI, ${ }^{6}$ MUHAMMAD ALI ALBANA

\begin{abstract}
Fakultas IImu Komunikasi, Universitas Islam Bandung, Jl. Tamansari No.1 Indonesia email: ${ }^{1}$ alexsr@gmail.com, ${ }^{2}$ ferry@unisba.ac.id, ${ }^{3}$ ratri.rizki@yahoo.com, ${ }^{4}$ endri_listiani@yahoo.com, ${ }^{5}$ dadiahmadi@unisba.ac.id, ${ }^{6}$ muhammadalialbana@gmail.com
\end{abstract}

\begin{abstract}
The phenomenon of Korean culture fans, especially fans of Korean Pop music (K-pop) in Bandung, showing their unusual behaviors, such as screaming loudly over their idols, doing fan chants, covering dances, feeling angry if their idols being insulted by haters, and putting K-pop as their role model. This is interesting to study. Schutz's phenomenological analysis is used to examine the phenomenon of K-pop fans in terms of their experiences. The subject of this research is a fan of K-pop and a member of Korean culture lover community. Based on the results of observations and interviews, there are three self-concept transformations of informants, namely (1) byeonhwa namnyosongeui (변화남녀성의), i.e. transformation of the masculine self-concept into feminine; (2) byeonhwa dad-eun yeollin (변화성의열린), i.e. transformation of the introvert self-concept into extrovert; and (3) byeonhwa uigyeon bad eun (변화의견받은) which can be interpreted as transformation of the closed-minded self concept into open minded that appreciate other people's opinions.
\end{abstract}

Keywords: K-pop fans, definition, transformation, self-concept.

\section{Introduction}

South Korea is currently known as one of the countries in Asia which has successfully introduced many new things to the world, particularly in electronics, fashion, and popular culture. One of the areas with rapid development and brings great influence to many countries is Korean popular culture in the form of pop music and drama. Korean pop music is known as Korean Pop or K-pop, while Korean drama is shortened to K-Drama or Indonesian people call it Drakor which means Drama Korea (Korean Drama).

In South Korea, K-pop has been known since the late 90 's and at the beginning of 2000 with the entry of Japan pop music and Western music that began to affect musical style of South Korean musicians /artists. Furthermore, the wave of Korean pop culture known as Korean wave or Hallyu (한류) started to spread in Southeast Asia, China, and Japan (Shin, 2012:150). The world began to take notice of South Korea in 2002 World Cup. Korean culture fever started with drama series The Jewel in The Palace and Winter Sonata which brought Korea's cultural values and pop music to different countries in the world. According to Asia Times January 2 edition, 2004, the Ministry of Foreign Affairs of South Korea in early 2004 issued a policy to promote K-drama in Asian region for free. The ministry supplied K-dramas to many tv stations with the aim to spread the popularity of Korean pop culture to various countries in Asian region in particular.

Meanwhile, Korean pop culture started to invade Indonesia through popular K-dramas broadcasted on private televisions in 2000. At the beginning of 2002, Korean drama Endless Love broadcasted on Indosiar, one of the private televisions which later aired a lot of Korean dramas. Ever since, no less than 50 titles of Korean dramas crowded the entertainment industry in the country. The popularity of Korean drama made Indonesian fans became interested in all things about Korea, ranging from fashion, cosmetics, smartphones, to songs of K-drama

Received: April 02, 2018, Revision: Agustus 16, 2018, Accepted: December 11, 2018

Print ISSN: 0215-8175; Online ISSN: 2303-2499. DOI: http://dx.doi.org/10.29313/mimbar.v34i2.3729.414-422

Accredited B based on the decree No.040/P/2014, valid on February, 18, 2014 until February, 18, 2019. Indexed by DOAJ, Sinta, IPI 
soundtracks.

Often the original soundtrack of K-drama sung by the actor himself/herself and vice versa, a K-pop singer plays the main character in a K-drama. This harmonization and dynamics of music and drama later created captivating works of art of popular culture which made K-pop sought after and popular in Indonesia. Entering the year 2011, K-pop began venturing to number of countries in Asia, Europe, Africa, and America. Korean celebrities who always look stunningly beautiful and handsome, of course, adding the hysteria to the fans, especially with the presence of a boyband and a girlband offering pop and crisp music completed with synchronized dance choreography which formulated K-pop as a wonderful and never boring music to listen to. The existence of internet as a new medium of technology increasingly facilitates the community to get information about K-pop songs and celebrities in various formats (text, audio, and video). It is accelerating the spread of Korean popular culture throughout the world, including Indonesia

The inclusion of K-pop music in Indonesia was initialized by the presence of female K-pop singer called BoA who was recognized as the Queen of K-pop since she introduced K-pop music to other countries and succeeded worldwide. Next was the appearance of K-pop male singer named Rain who previously known as the lead actor in Full House drama alongside actress Song Hye Kyo. Full House was aired by one of the private television stations and succeeded in winning the hearts of Indonesian audience. This positive responses opened the opportunity for $\mathrm{K}$-pop culture to target Indonesia as $\mathrm{K}$-pop market. Other Korean singers started to come afterwards and held their concerts in Indonesia. The outbreak of K-pop commenced by the arrival of K-pop group of singers/ dancers known as boyband and girlband idols to Indonesia and performed their concerts. Popular idols among K-pop fans in Indonesia, among others, are Super Junior, TVXQ, Bigbang, and SNSD for the first and second generations; while the next generations are EXO, BTS, Wanna One, Ikon, Black Pink, and Twice to name some. K-Pop consuming market exhibits a power-law distribution in number of released song for each artist (Y. J. Kim, 2018: 1249). The acceptance of K-pop in Indonesia has created communities of K-pop fans which growing in some major cities in Indonesia.
The greater interest in Korean pop culture has encouraged the Korean Tourism Organization to hold a survey in June 2011 to 12,085 visitors of www.visitkorea.co.kr from 102 countries. The survey was held in order to find out the large level of interest of visitors towards Korean wave or K-pop cultural development wave in the world.

The survey results indicated that compared to Korean drama and film, K-pop fans are the most website visitors. $\mathrm{K}$-pop is a type of Korean music consisting of dance, mixed songs of hip-hop, electro, and R\&B produced and sung by Korean people (figure $1)$.

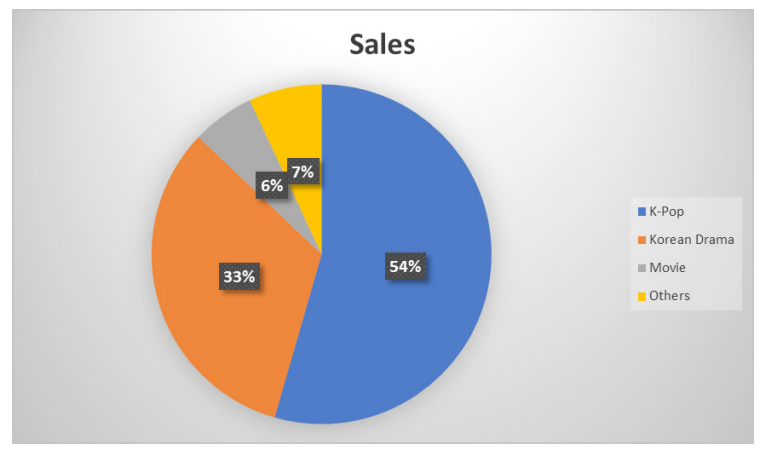

Figure 1. Survey on www.visitkorea.co.kr

Both K-pop and K-dramas have different fans segmentation. Based on the result of short interviews with some K-pop and drakor fans, it turned out that K-pop was the most favored by teenagers and early adults ( 24 years old) fans, while young adults and matured ones more prefer to K-drama. According to the research informants, the most $\mathrm{K}$-pop and drakor fanatic fans are women, but there are also men and they join particular Korea's fan communities.

Just like other cities in Indonesia, Bandung has also several Korean enthusiast communities/clubs, such as HKLCB (Homey Korean Language Club of Bandung)/Homey which is established for those who are interested in Korean culture and language. HKLCB is successfully attracted public interest and $\mathrm{K}$-pop fans by providing teachers from Korea to teach the language. Other community is $\mathrm{BKC} /$ Hansamo (Bandung Korean Community) as the largest Korean lover in Bandung with members who have a great passion for $\mathrm{K}$-pop and everything about Korea. There are also communities of fandom (fandom is a group of certain K-pop idol fans gather together and usually has its own unique name), such as Sone for Korean girlband SNSD fans, Cassiopeia Community 
for Korean boyband TVXQ fans, HotBan (Hottest Bandung) for 2PM fans, VIP Bandung for Big Bang fans, Shawol Bandung for Shinee fans, ELF Bandung for Super Junior lovers, EXO-L for EXO fans, and many others.

Those communities exist with the purposes of either studying the languages and cultures of Korea or supporting their idols. The latest is proven by the successful of many idols' concerts with sold out tickets sales, even though certain tickets' prices were quite expensive.

Based on K-pop fever phenomenon, the researchers did short interviews with some $\mathrm{K}$-pop fans about what made them interested in $\mathrm{K}$-pop and their experiences before and after they became K-pop fans. Based on the results of the interviews, the informants stated that initially they just wanted to try new things by knowing and hearing $\mathrm{K}$-pop music. However, by holding different reasons, they slowly become interested in and enjoying all things about Korea, especially K-pop. This new interest affects the way they assess things, ranging from how to dress, beauty standard of a person, and judging other things which is always linked to their perception of Korea. They are also very enthusiastic when talking about and finding out things related to popular K-pop idols, even some of them are die-hard fans (very fanatic about their idols). They often look for and never stop talking about their favourite K-pop idols, both in virtual world (social media) and everyday life. Internet is their best option to search information about K-pop Idols. K-pop fans spend a lot of time greeting and interacting with their fellow fans in virtual world and look for the latest news of their K-pop idols.

Based on the researchers observations, there are some changes in how they perceive themselves after they become K-pop fans compared to their lives before. This is a basic question which intrigued the researchers to probe further about the change of informants' self-concept once they become K-pop fans. K-pop also makes specific policy recommendations to accompany the analysis (Sim, 2017).

In elaborating self-concept tranformation of $\mathrm{K}$-pop fans before and after knowing $\mathrm{K}$-pop, the researchers used phenomenological study to delve the experience of K-pop fans. Phenomenological study allows the researchers to study self-concept which also known as 'the study of direct awareness' with a phase that self-acceptance exists due to the consciousness of self and the environment. The phenomenological approach assumes that behavior is not only influenced by the experiences of the past and present but also by personal meanings in which each individual attached themselves to his perception of those experiences.

The use of a theory in phenomenological research is essentially principled a priori, which is not preceded by and based on a specific theory. The research of phenomenology thus departs from the perspective of philosophy about "what" to be observed and how to observe it.

The basic premises used in the research of phenomenology are as follows (a) An event would mean something for those who experienced it firsthand; (b) Objective understanding is mediated by subjective experience; and (c) Human experience is in the structure of experience itself; it is not constructed by the researchers (Kuswarno, 2009: 58).

Phenomenological approach encourages social scientists to view various social symptoms differently. There are also opinions that this approach makes social science finds itself. Phenomenological approach used in this study is the typification of Alfred Schutz' phenomenology. Schutz stated that social research is very different from science research such as chemistry, and added that in social science a researcher need to be face to face with research object directly.

Some phenomenological questions Schutz strives to answer are how the actor creates a subjective world of impersonal? How social reality is formed, maintained, and changed? How is it related to the resilience and social order? Schutz's answers, being summarized by the researchers, are as follows: first, there are actually social recipes in everyone's mind, i.e. the conceptions about behavior and how to behave appropriately. Second, human mind is not only made up of one or two recipes (either in the form of rules, concepts, and other information). Third, particularly, there are some points about knowledge stock which are important to be propounded as follows:

(1) The knowledge stock is basically a social reality; 2) The knowledge stock is rarely made as targets of reflection by the owner; 3) The knowledge stock of individual is not something received from birth, but it is gained by learning; 4) Part of knowledge stock content is distinctively owned by one individual (based on experience); 5) Individual knowledge stock will raise individual "typification" over the daily 
life situation (Sobur, 2014: 53-54).

Phenomenological approach continues the trend of self-concept introduction which originally has no clear distinction between known-self and identifier-self. Rogers developed a theory of enforcing a self-concept of phenomenology of behavior and counseling techniques with self-concept as a bottom line. Basic considerations of phenomenological approach, as developed by Rogers (in Burns, 1993:201) are: (a) behavior is a product of someone's perception; (b) perception is phenomenological rather than 'real'; (c) perception should be linked to the existing field organization, in which the most important point is self-concept; (d) self-concept is things perceived or a concept where values introjected from cultural pattern are gathered; (e) behavior is governed by self-concept; ( $f$ ) self-concept is relatively consistent over time and situation, and generates behavior patterns which are relatively consistent; $(\mathrm{g})$ self-defense strategies are utilized to prevent oddities occurred between the experience and the recognized self-concept; $(h)$ there is a basic urge of self-actualization.

Self as described by William James in Sobur (2014: 499-500), which later developed, is the composition of thoughts and feelings turned into consciousness of a person regarding his individual existence, his observations of his belongings, his understanding of who he is, and his feelings about his characters, quality and everything he has. Oneself is the total sum of what we call his.

Self-concepts are cognitive structures that can include content, attitudes, or valuative judgments and are used to make sense of the world, focus attention on one's goals, and protect one's sense of basic worth (Oyserman, Elmore, \& Smith, 2012:69104). It can be mean that someone's mental concepts of thinking about himself are the content of self concept. (Kühnen, U., \& Oyserman, D.: 2002).

Self can actually indicates an overall subjective environment of someone. For a person himself/herself, the definition of self can be describe as "the centre of experience and needs" (Howie, 1945, in Sobur, 2014:500). Self-concept would be reflected in our behaviors and statements as our interpretation of interaction with others and others' responses towards us.

Self concept in adolescence is more settle or stable. Adolescence is where the development of one's self-concept really takes off. This is the stage in which individuals play with their sense of self, experimenting and comparing, and begin developing the basis of self-concept that will likely stay with them throughout the rest of their lives, eventhough for some people this self-concept can change due to many reasons.

The self-concept is a perception about yourself that relatively stable, as Ronald B. Adler describes "Self concept is the relatively stable set of perceptions you hold of yourself." Self-concept is an individual view on who the individual is that can be retrieved from information given by others to that individual (Mulyana, 2000: 7). This self-concept will change depending on what kind of environment he/she is living in. For example, an employee who will get retired. $\mathrm{He} / \mathrm{she}$ will experiences a change in his/her self-concept about retirement either with positive or negative perception, in which the environment take parts for shaping such perception.

It is quite similar to the self-concept change experienced by K-pop fans, where they initially just want to enjoy Korean pop music, but then gradually getting curious about it and start searching for their K-pop idols, and eventually crowning them as their forever idols.

Self-concept can change as it is expressed by Raimy dan Comb (Burns, 1993:324): "Self concept not only influences behavior but it is a self already and restructured behavior and unsatisfied". This view shows that self-concept which has already formed would have the possibility to change due to the interaction with its environment and involves two processes: first, awareness of change. Individual relationship with his surrounding environment or culture has an important role since the experiences acquired from such interaction can lead to a change in self-concept. That change depends on two main functions, i.e. the self-concept perception and the individual's ability to see the change in him as others see it. Second, the acceptance of new concepts in individual self. This acceptance process can be formed gradually or suddenly and occurs from existing situations.

In the process, self-concept is shaped through life experiences formed by reactions to others. During adolescence, a person is drawn towards activities that facilitate the self-image projection of him/her initiated by 
others and has a relation in achieving his/her goals. The self-concept is important because it can help determining what to do in every situation.

According to Felker (Burns, 1993:203), there are three main functions of self-concept: first, the custodian of internal self-concept constitution. If an individual has mismatched ideas, feelings, and perceptions, it would triggered a situation which psychologically unpleasant for him. This condition called a state of dissonance, where an individual has the motivation to achieve better circumstances. Second, self-concept as the interpretation of experiences. Self-concept is one of the defining aspects of behavior which can be seen from how life experiences being interpreted. Individuals usually give their own meaning to each of their experiences. Third, the self-concept as an expectation. Selfconcept determines what can be expected to happen, in respect of himself as a valuable person, wanting others to treat him in accordance with what he has acquired.

\section{Research Method}

This study is a qualitative research and uses the phenomenological approach of Alfred Schutz. Schutz thinks that the object of social science research is basically related to the interpretation of reality, so that social researchers must also interpret the observed reality. By doing the same interpretation, researchers can enter into the world of interpretations of people who are the object of this research.

Phenomenological analysis reconstructs the world of human life in the form of their experiences by paying attention to meaning, words and other behaviors, and the presumption of a supply of knowledge as a collection of receipts that guide humans in behaving in a society.

The informants of this research are $\mathrm{K}$-pop lovers residing in Bandung who have a criteria as K-pop fans with various levels of fanaticism. Subject of the research was selected by the reason that they have become $\mathrm{K}$-pop fans/K-pop lovers for a long time (Table 1 ). Number of informants in this study is not significant since the focus lies on data accuracy of the research results. Informants were sorting out using non-probability sampling/ non-random with purposive sampling type. Based on their willingness, informants' experiences and activities as K-pop fans will be explored to obtain data for the research.

Table 1 Subject Biographies

\begin{tabular}{llll}
\hline No & Informant & Age & $\begin{array}{l}\text { First Time } \\
\text { Knowing K-pop }\end{array}$ \\
\hline 1 & $\begin{array}{l}\text { Synthia Pramitha } \\
\text { Bangun (Ijo) }\end{array}$ & 26 & Early 2005 \\
2 & $\begin{array}{l}\text { Aisha Salsabila } \\
\text { Tisyani (Sasha) } \\
\text { Yusniar }\end{array}$ & 26 & June 2009 \\
3 & Rachman (Ijus) \\
4 & $\begin{array}{l}\text { Veryna Rachman } \\
\text { (Veryn) }\end{array}$ & November 2008 \\
5 & $\begin{array}{l}\text { Gita Annisa } \\
\text { Maharani (Gita) }\end{array}$ & 26 & Since 2008 \\
\hline
\end{tabular}

Source: Research Data

Methods of data collection used in this study are unstructured interview and observation. Generally, interview method is divided into structured and unstructured (Mulyana, 2000:180). The researchers took unstructured, open, and in depth interview. It was conducted informally with the goal of keeping informants comfortable and relax in answering all the questions asked. Meanwhile, qualitative observation is applied in the context of a natural event, following the natural path of observing life. Qualitative observation is not limited to measurement categorizations (quantitative) and predicted responses in advance. Qualitative observation is free to examine the concepts and categories of each event, then give meaning to the subject of research or observation (Hasanah, 2016: 23).

The researchers performed in-depth interviews with informants of K-pop fans. The way of interviewing is following the suggestion from Moustakas who stated that "The phenomenological interview involves an informal, interactive process and utilizies open-ended comment and questions" (Moustakas, 1994:114). Observation is needed in this research to understand the process of interview and comprehend its result's context.

\section{Result and Discussion}

One's self-concept is he/she from his/ her point of view (Burns, 1993:44). Selfconcept is an individual's view on who he/ she is which retrieved from information given by others (Mulyana, 2000:7). It is the process of identifying oneself by a concept of assessing oneself through information 
received and manage it to appraise who he/ she is. This research will discuss about how a K-pop fan transform and judge himself/herself through the process of first knowing $\mathrm{K}$-pop and eventually becoming a fan.

$\mathrm{K}$-pop fans are people who change their point of view from originally knew nothing about K-pop, then ended up becoming big fans. Their first encounter with K-pop occurred in different ways. One informant felt funny when they first knowing K-pop; some knew K-pop while they accompanied their friends to do spazzing (watching K-pop music video and become hysterical for their idols appearances).

Based on the interview results and refers to the Schutz's typification analysis, there are three types of transformation occurred to the main informants categorized by the researchers, namely: (1) byeonhwanamnyosongeui / 변화남녀성의, self-concept transformation from masculine women to feminine women; (2) byeonhwa dad-eun yeollin (변화닫은열린), self-transformation from introvert personality to extrovert; and (3) byeonhwa uigyeon badeun (변화의견받은), self-transformation from close-minded to open-minded and willing to appreciate other people's opinions. The following are elaboration and explanation of three types of self-concept transformations in Bandung.

\section{Byeonhwanamnyosongeui (변화남녀 성의)}

This is the kind of self-concept transformation from masculine women to feminine women. Sasha, a small girl with hijab (moslem's veil) and love to dress the way boys are (tomboy), has experienced such transformation. Her male-dominated campus environment influenced Sasha to stay calm and relax and pay less attention to her appearance, which can be seen from the observation of the researchers in the field. Sasha, the eldest of two siblings, does look tomboy with a fondness for heavy metal, rock music, and something alike. She is quite extrovert and having no hesitation in talking about things which considered taboo for most women. She loves wearing casual t-shirts, jeans, and sneakers as her daily clothing. She also prefers to put no makeup and has masculine impression on her.

However, soon after she knew and eventually loves K-pop, she began to transform herself into a more feminine figure by wearing pretty, colorful outfits. Sasha often puts on make-up imitating her idol, SNSD or Girl's Generation who are famous for their pretty faces and great songs. Seeing her other idol, Korean boyband Big Bang wearing make-up, she thought that even men look good with make-up, then surely she -as a womanwould be more than appropriate to wear make-up. In accordance with the meaning she gave to K-pop, she finally did see K-pop as a powerful inspiration which can change her into someone with different perception over herself. The case of Sasha as one of the research informants is an example of self-transformation from masculine figure to feminine. Masculine is the nature of man and becomes a symbol of the difference between men and women, while feminine represents the natural trait attached to women.

Sasha admitted that she has now started looking at herself as a feminine rather than a masculine after knowing K-pop. K-pop taught her that make-up can change someone. Not only transformed into a feminine figure, K-pop has also increased her level of confidence. Sasha's self-concept transformation inspired by $\mathrm{K}$-pop made her learn a lot of things: becoming more confident, having more friends, and being open to new things. K-pop brought a new culture for Sasha. She learned new culture and language due to the love and curiosity of the language used by K-pop artists. Having a change in assessing herself after knowing K-pop, Sasha defines K-pop as an inspiration that has made her a better person.

\section{Byeonhwa dad-eun yeollin (변화닫은 열린)}

The self-concept transformation from introvert personality to extrovert formation experienced by an informant named Ijus, who claimed that she has gone through selfconcept transition from introvert to extrovert. Introvert can be defined as someone quiet, reserved, and reticent. The change of personality is especially noticeable in the way of communicating which characterize the introvert and extravert. In line with Jung's original conception of introverts and extraverts, which distinguished between them on the basis that introverts are exhausted by social interaction while extraverts are energized by it (Duffy, Helzer, Hoyle, Helzer, \& Chartrand, 2018: 5). Before knowing K-pop and join K-pop lovers community, Ijus is an introvert person which can be seen from 
the way she delivers messages through a long process with storaging first, processing the messages, and delivering them. After joining the community, she shows the opposite personality. She undergoes the process of self-transformation and becomes an open person who is easier to get along with. Ijus like to dance and it becomes her motive to learn K-pop dance. She honed her dancing skill by entering K-pop cover dance competitions. Her recent favourite group is NCT from SM Entertainment, which known for their dancing skills and good voices too.

Ijus interprets $\mathrm{K}$-pop as the object of her hobby because by joining K-pop activities, she feels positive things, be friends with other dance enthusiasts, interacts and mutually shares the dance exercise and experiences. Her hobby before K-pop was football. In appearance, she is just like a tomboy girl Sasha, but the change she felt the most is her open personality toward other people, especially her fellow K-pop fans.

Not only experiencing the self-concept change of being open to others, Ijus has also changed her concept towards the opposite gender. She started to choose her ideal type of man as closely as possible to her bias/ idols. Ijus admitted that one negative side of becoming a $\mathrm{K}$-poper is the difficulty to let go K-pop as something that has been taking most of her time.

\section{Byeonhwa uigyeon bad-eun (변화의 견받은)}

This kind of self-concept transformation can be interpreted as a self-concept transformation from being closed-minded person to open-minded one and willing to appreciate other people's opinions. It occurred to Ijo, a fan of famous K-pop group EXO. Admiring the good attitudes shown by her idol in respecting other groups' achievements, Ijo feels that she becomes more open to other people's opinions and could receive the fact that there are other K-pop fans who love other idols, not only her idols. With those changes, Ijo interprets K-pop as one of the colors that will always becomes part of her life.

Based on in depth interviews and observations, the researchers discovered that not all of the informants as the subject of this study experienced self-concept transformations. In short, the self-concept transformation of $\mathrm{K}$-pop fans can be seen in the Table 2.

The transformation of self-concept experienced by informants shows that selfconcept can change even though humans have grown up. Self-concept is the overarching perspective we have on who we are. Each of us has our own unique self-concept, different from the self-concept of others and from their concept of us. However, there are some characteristics that all of our self-

Table 2

The Self-Concept Transformations of K-Pop Fans

\begin{tabular}{|c|c|c|c|}
\hline \multicolumn{3}{|c|}{ Self-Concept Transformation } & \multirow[b]{2}{*}{ Informant } \\
\hline Category & Before Knowing K-pop & $\begin{array}{l}\text { After Knowing } \\
\text { K-pop }\end{array}$ & \\
\hline $\begin{array}{l}\text { namnyosongeui } \\
\text { (변화남녀성의) }\end{array}$ & $\begin{array}{l}\text { Viewing herself as a tomboy } \\
\text { person/masculine and } \\
\text { paying less attention to her } \\
\text { appearance }\end{array}$ & $\begin{array}{l}\text { Viewing herself as } \\
\text { someone who start to } \\
\text { enjoy putting on make- } \\
\text { up and wearing feminine } \\
\text { dresses }\end{array}$ & Sasha \\
\hline $\begin{array}{l}\text { byeonhwa dad-eun } \\
\text { yeollin } \\
\text { (변화닫은열린) }\end{array}$ & $\begin{array}{l}\text { Viewing herself as someone } \\
\text { who hard to get along with } \\
\text { and also not easily be friend } \\
\text { with (introvert) }\end{array}$ & $\begin{array}{l}\text { Viewing herself as an } \\
\text { outgoing person, excited } \\
\text { to learn and do new } \\
\text { things, one of which is } \\
\text { performing a cover dance } \\
\text { (extrovert) }\end{array}$ & Ijus \\
\hline $\begin{array}{l}\text { byeonhwa uigyeon } \\
\text { bad-eun } \\
\text { (변화의견받은) }\end{array}$ & $\begin{array}{l}\text { Viewing herself as someone } \\
\text { who can not accept others' } \\
\text { opinion or others'favourites } \\
\text { rather than her own } \\
\text { favourites/idols, and easy to } \\
\text { underestimate things }\end{array}$ & $\begin{array}{l}\text { Viewing herself as } \\
\text { someone who can accept } \\
\text { others' opinion and does } \\
\text { not quickly underestimate } \\
\text { things }\end{array}$ & Ijo \\
\hline
\end{tabular}


concepts have in common. Self concept can be transformed because of several things that occur in human life, such as the way they perceive or give meaning of something in their life.

This research shows that in some people, K-Pop has a very strong influence so that it can change their self-concepts and even behaviors. It also being affected by the meaning of K-Pop for the K-Pop fans.

Basically, the uniqueness of thinking that each individual will always give meaning to things that he encountered in the environment and surroundings. The meaning of itself will develop with the surrounding environment and can not be separated from communication between K-Pop fans themselves, not only limited to individuals who interpret it as presented in Table 3.

\section{Table 3 \\ The Definition/Meaning of K-pop for the Fans}

\begin{tabular}{lll}
\hline No & K-pop Definition & Informant \\
\hline 1 & The color of life & Ijo \\
2 & Inspiration & Sasha, Veryn \\
3 & Object of hobby & Ijus, Gita \\
\hline
\end{tabular}

Source: results of Research, 2018

The process of meaning that occurs in each informant is passed with the experience and knowledge of each informant regarding K-Pop, such as Ijo's knowledge of K-Pop as a genre of music inherited from Korean culture and becoming famous today, it plays pop music mixed with other musical genres such as hiphop, electro, and other musical genres. Ijo herself initially liked J-Pop, but that didn't make her a fanatical fan like being a K-Pop fan.

The process of meaning experienced by Sasha is a separate learning for her. Her knowledge of K-Pop makes Sasha more interested and difficult to break away from. High enthusiasm and high delusions are often experienced by Sasha, especially when someone talk about bias of her idol. The interaction between Sasha and other K-Pop fans is also a point of forming meaning in K-Pop.

The meaning that happened was not separated from interaction and environment in Korean community itself, such as HKLCB that became the place for informants to become members, learn languages, culture and finally bring them together with other K-Pop fans. Although not all who join the HKLCB community are fans of K-Pop, the effects of friends who are fans of K-Pop can be contagious. This was proven by Sasha and Ijus, who were only introduced to one K-Pop artist video. Ijo himself found friends who loved Super Junior in this community, she diligently studied the language and culture of her idol bias.

K-Pop as inspiration was stated by Sasha and Veryn that they had become person who dared to try many new things because of the great influence of K-Pop. Then by taking positive things about the struggle of K-Pop artists to become successful, they are inspired to also struggle to maintain their passion for K-Pop which is not easy thing to do.

It is often happen that many of their friends and people around them do not understand the way of K-Pop fanatics thinking. They do not understand the behavior of K-Pop fans. Meanwhile, Ijus and Gita interpreted K-Pop as a hobby that had given them many forms of pleasure and now dominated their lives.

\section{Conclusion}

Hallyu (한류) waves caused everything about Korea become "memorable" and sought after, including Korean music better known as K-pop. People's curiosity about K-pop, either the songs or idols/celebrities, can be satisfied by scrolling through internet and instantly get whatever information they want/ need. Initially, many of them just want to try out new things by knowing and hearing $\mathrm{K}$-pop music, but they gradually enjoy the K-pop music at the end. By applying Schutz's phenomenological study, this research found self-concept tranformation of $\mathrm{K}$-pop fans before and after they know K-pop.

Based on research findings and results of Schutz's typification analysis, there are three types of self-concept transformation occurred: byeonhwa namnyosongeui ( 변화남녀성의), i.e. transformation of the masculine self-concept into feminine, (2) byeonhwa dad-eun yeollin (변화성의열린), i.e. transformation of the introvert selfconcept into extrovert, and (3) byeonhwa uigyeon bad-eun (변화의견받은) which can be interpreted as transformation of the closedminded self-concept into open-minded that appreciate other people's opinions. 


\section{References}

Burns, R.B. (1993). Konsep Diri, Teori, Pengukuran, Perkembangan, dan Perilaku. Jakarta: Arcan.

Duffy, K. A., Helzer, E. G., Hoyle, R. H., Helzer, J. F., \& Chartrand, T. L. (2018). Pessimistic expectations and poorer experiences: The role of (low) extraversion in anticipated and experienced enjoyment of social interaction. PLOS ONE, 13(7), 1-22. https://doi.org/10.1371/journal. pone.0199146

Hasanah, H. (2016). Teknik-Teknik Observasi. At-Taqaddum, 8(1), 21-46. https://doi. org//10.21580/at.v8i1.1163

Kühnen, U., \& Oyserman, D. (2002). Thinking about the self influences thinking in general: cognitive consequences of salient self-concept. Journal of Experimental Social Psychology, 38(5), 492-499. Retrieved 12 28, 2018, from https:// sciencedirect.com/science/article/pii/ s0022103102000112

Kuswarno, Engkus (2009), Fenomenologi: metode penelitian komunikasi: konsepsi, pedoman, dan contoh penelitiannya. Bandung: - Widya Padjadjaran

Moustakas, C. (1994). "Phenomenological
Research Methods," Sage Publications. London

Mulyana, Deddy. (2000). IImu Komunikasi Suatu Pengantar. Bandung: PT Rosdakarya.

Oyserman, D., Elmore, K., \& Smith, G. (2012). Self, Self-Concept, and Identity. In M. R. Leary \& J. P. Tangney (Eds.), Handbook of Self and Identity (2nd ed., pp. 69-104). The Guilford Press.

Shin, H. (2012). The success of hopelessness: the evolution of Korean indie music. Perfect Beat, 12(2), 147-165. https://doi. org/10.1558/prbt.v12i2.147

Sim, H., Kim, S., \& Lee, B. (2017). K-Pop Strategy Seen from the Viewpoint of Cultural Hybridity and the Tradition of the Gwangdae. Kritika Kultura(29), 292317. Retrieved 12 20, 2018, from https:// journals.ateneo.edu/ojs/index.php/kk/ article/view/kk2017.02914

Sobur, Alex. (2014). Filsafat Komunikasi, Tradisi dan Metode Fenomenologi. Bandung: PT Rosdakarya.

Y. J. Kim, S. Lim, Y. J. Park, S. W. Son. Quantitative Analysis of K-Pop Writers' Network by Using K-Pop Lyrics. New Phys.: Sae Mulli 68, 700 (2018). https://doi.org/10.3938/ NPSM.68.700 